This item was submitted to Loughborough's Research Repository by the author.

Items in Figshare are protected by copyright, with all rights reserved, unless otherwise indicated.

\title{
Is the hyporheic zone a refugium for aquatic macroinvertebrates during
}

severe low flow conditions?

PLEASE CITE THE PUBLISHED VERSION

http://dx.doi.org/10.1127/1863-9135/2010/0176-0377

PUBLISHER

(C) E. Schweizerbart'sche Verlagsbuchhandlung

VERSION

NA (Not Applicable or Unknown)

LICENCE

CC BY-NC-ND 4.0

\section{REPOSITORY RECORD}

Wood, Paul J., A.J. Boulton, Sally Little, and Rachel Stubbington. 2019. "Is the Hyporheic Zone a Refugium for Aquatic Macroinvertebrates During Severe Low Flow Conditions?”. figshare.

https://hdl.handle.net/2134/13054. 
This item was submitted to Loughborough's Institutional Repository (https://dspace.lboro.ac.uk/) by the author and is made available under the following Creative Commons Licence conditions.

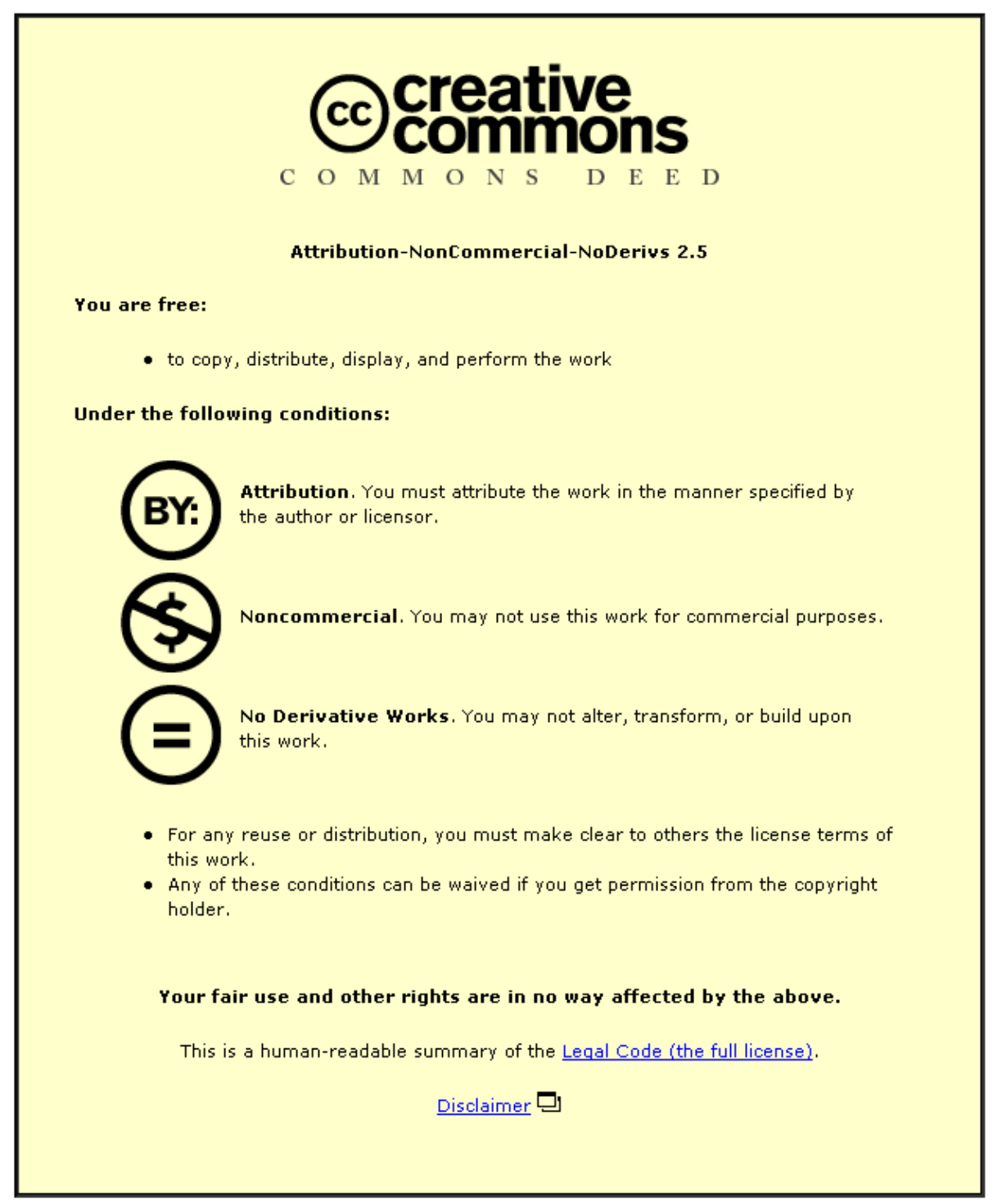

For the full text of this licence, please go to: http://creativecommons.org/licenses/by-nc-nd/2.5/ 
Is the hyporheic zone a refugium for aquatic macroinvertebrates during severe low flow conditions?

\section{Wood PJ ${ }^{1}$, Boulton $\mathrm{AJ}^{2}$, Little $\mathrm{S}^{1}$ and Stubbington $\mathbf{R}^{1}$}

1. Department of Geography, Loughborough University, Loughborough, Leicestershire, LE11, 3TU, UK.

2. Ecosystem Management, University of New England, Armidale 2350 New South Wales, Australia.

\section{Author for Correspondence \\ Dr Paul Wood \\ Department of Geography \\ Loughobrough University \\ Loughborough \\ Leciestershire \\ LE11 3TU \\ UK \\ Email:- p.j.wood@,lboro.ac.uk \\ Tel: 0044 (0)1509 223012 \\ Fax: 0044 (0)1509 223930}




\begin{abstract}
The potential role of the hyporheic zone as a refugium for stream invertebrates during hydrological perturbations was acknowledged more than five decades ago. However, field evidence to support the hyporheic refuge hypothesis during periods of flow recession and severe low flow remains equivocal. Some studies report fauna using the hyporheic zone during periods of flow cessation whilst others have recorded little or no refuge use due to limited habitat availability or harsh abiotic conditions. We assessed aquatic macroinvertebrate community changes associated with severe low flow conditions during a severe supra-seasonal drought on the Little Stour River (UK). Paired benthic and hyporheic samples were collected from four sites (two perennial, two intermittent) on the upper reaches of the river. The number of benthic taxa and the proportion of benthos (particularly the amphipod Gammarus pulex) within the hyporheic zone relative to those in the benthic samples increased significantly during the latter stages of the drought at all sites. These changes coincided with elevated benthic and hyporheic water temperatures rather than a reduction in river discharge alone. The abundance of obligate hypogean macroinvertebrates also increased during the latter stages of the event, suggesting that hypogean taxa may also utilise the shallow hyporheic zone during adverse environmental conditions. Our results, based on paired surface-hyporheic field samples at multiple sites, support the hyporheic refuge hypothesis within a temperate groundwater-dominated stream during severe drought. The results also clearly demonstrate the importance of considering surface-subsurface linkages when assessing responses to disturbance in streams.
\end{abstract}

Keywords: benthos, hyporheos, drought, supra-seasonal event, disturbance, surfacegroundwater interactions, hyporheic refuge hypothesis. 


\section{Introduction}

The last two decades have seen a proliferation of research on the hyporheic zone of riverine ecosystems (Krause et al. 2009). This reflects the growing acknowledgement of the importance of the hyporheic zone to the ecological functioning of riverine ecosystems (Boulton et al. 1998; Jones \& Mulholland 2000), its contribution to biodiversity (DoleOlivier et al. 2009), the maintenance of economically important fisheries (Malcolm et al. 2004), and dispersion of potential pollutants (Gandy et al. 2007), and its significance for holistic river restoration (Boulton 2007; Kasahara et al. 2009). It is also increasingly being recognised that the hyporheic zone is a 'hotspot' for biogeochemical processes and central to the transient storage of nutrients within lotic ecosystems (Mulholland et al. 2008; Pinay et al. 2009), strongly influencing the physical, chemical and biological characteristics of both surface and groundwater ecosystems (Fisher et al. 1998; Kasahara et al. 2009).

The utilization of the hyporheic zone by benthic fauna as a refugium was first reported by Orghidan $(1953 ; 1959)$ in the Bughea valley, southeast Romania, when all water in the surface stream was completely frozen during the winter months. Benthic fauna were located by digging through the ice and into the alluvial sediments to a depth of $30 \mathrm{~cm}$. This evidence appears to have been largely overlooked in the following years until freshwater scientists began to explore the vertical distribution of fauna within river beds (Coleman \& Hynes 1970) leading to the 'hyporheic refuge hypothesis' proposed by Williams \& Hynes (1974). Since then, the role of the hyporheic zone as a potential refugium has received increasing attention, with a particular emphasis on hydrological extremes associated with floods and droughts (Palmer et al. 1992; Marchant 1995; Dole-Olivier et al. 1997; Boulton et al. 2004; Stubbington et al. 2009a). 
Hydrological variability is a significant factor structuring most stream communities (Lytle \& Poff 2004; Monk et al. 2008). The response of benthic fauna to floods and droughts has been studied in detail (e.g., Lake 2000; Suren \& Jowett 2006; Stubbington et al. 2009a) although the availability of long-term baseline data prior to individual events often limits the ability to accurately gauge the full extent of community change or recovery processes (Lake 2003; Bêche et al. 2009). Numerous studies have examined benthic faunal use of the hyporheic zone as a result of increased discharge and floods, and while some do support the hyporheic refuge hypothesis (Puig et al. 1990; Dole-Olivier \& Marmonier 1992, Marchant 1995), an almost equal number report limited or no evidence (Palmer et al. 1992; Boulton et al. 2004; Olsen \& Townsend 2005).

Evidence of benthic (surface) faunal use of the hyporheic zone as a refugium during low flows and drought conditions is similarly equivocal. Some studies have reported the occurrence of benthic and obligate hypogean fauna within the hyporheic zone during periods of river bed drying and flow cessation in naturally intermittent streams (Griffith \& Perry 1993; Clinton et al. 1996; Hose et al. 2005; Fenoglio et al. 2006) whereas other research on intermittent systems has reported little or no use of the hyporheic zone by benthic fauna (Delucchi 1989; Smock et al. 1994). In contrast, limited data exists for refugial responses to drought events in temperate perennial streams (Lake 2007; Wood \& Armitage 2004), and very few studies have simultaneously considered benthic and hyporheic macroinvertebrate community response to severe low flows (exceptions being James et al. 2008; Stubbington et al. 2009b).

In this paper, we compare the benthic and hyporheic macronvertebrate community response to declining flows and changing environmental conditions associated with the final stages 
of a supra-seasonal drought which spanned three years (2004-2006) on a largely perennial stream, the Little Stour River (Kent, UK). In particular, we examine the evidence for utilisation of the hyporheic zone by epigean benthos as a refugium during the drought. We also assessed the response by obligate groundwater/hypogean fauna (stygobites) to the changing conditions because few of these organisms have drought-resistant physiological adaptations (Boulton 2000). We hypothesised that: (i) the proportion of benthic organisms within the hyporheic zone would increase relative to those in epigean benthic samples if individuals actively utilised it as a refugium; and (ii) the response recorded at an individual site would reflect the historic flow / permanence of a site, with benthic organisms more likely to use the hyporheic zone as a refuge at sites that may become dry during summer low flow conditions.

\section{Materials and Methods}

\section{Study Site}

The Little Stour River (Kent, UK) is a small lowland stream $\left(51.275^{\circ} \mathrm{N} 1.168^{\circ} \mathrm{E}\right)$, draining a catchment area of approximately $213 \mathrm{~km}^{2}$. Mean annual precipitation within the catchment is c. $650 \mathrm{~mm} \mathrm{y}^{-1}$ (Wood \& Petts 1994). The sedimentary calcareous rocks within the catchment result in relatively high electrical conductivities (c. $580 \mu \mathrm{S} \mathrm{cm}^{-1}$ ). The highly permeable chalk catchment has a low drainage density, typical of groundwater-dominated streams (Sear et al. 1999), resulting in $11.5 \mathrm{~km}$ of perennial river channel. The river is usually perennial below the spring head, although a $1-\mathrm{km}$ reach has been dewatered on three previous occasions in the last century during supra-seasonal droughts $(1949,1991$ 1992 and 1996-1997), with the latter two events being studied in detail (Wood \& Armitage 2004). For further details of hydrology, site locations and physical characteristics, see Wood \& Petts (1999) and Wood et al. (2000). 
Prior to commencing the research, river flow had declined significantly compared to normal conditions due to very low rainfall during the winters of 2004-2005 and 2005-2006, leading to a reduction in groundwater levels and a prolonged period of low flow over most of southern England (Marsh 2007). This regional drought resulted in a marked decline in discharge on the Little Stour to levels comparable to the winters of 1991-1992 and 19961997 prior to dewatering of ephemeral sites (Stubbington et al. 2009b). Between January and March 2006, discharge was below average but remained relatively stable until the end of June. Discharge declined rapidly during July - early August, with the lowest discharge being recorded in mid-August $\left(0.053 \mathrm{~m}^{3} \mathrm{~s}^{-1}\right)$. Following higher than average rainfall during August, discharge began to increase, marking the start of flow recovery (Figure 1). Air temperature followed the typical seasonal pattern with maximum air temperatures being recorded in July and September (mean daily maximum temperature $21.9^{\circ} \mathrm{C}$ (SD 2.1) during July; $17.7^{\circ} \mathrm{C}$ (SD 1.7) during September). The drought conditions experienced during 2006 were extreme, with air temperatures during July being the warmest recorded within the 348-year long Central England Temperature Series (Prior \& Beswick 2007). Benthic and hyporheic water temperature tracked air temperature, with hyporheic water temperatures consistently lower than those recorded in the water column (Figure 2).

\section{Sampling}

During the latter stages of the drought in 2006 (April-October), paired benthic and hyporheic invertebrate samples were collected from four riffle sites. Two sites (the furthest upstream and downstream) experienced perennial flow throughout the documented history (Snell 1937; Wood \& Armitage 2004). The remaining two sites are usually perennial but experienced intermittent flow during two supra-seasonal drought events since 1990 (1991- 
1992 and 1996-1997). Intermittent flow occurred at these sites historically because water is lost to the riverbed where highly permeable alluvial deposits overlie chalk. The first of these sites flowed intermittently during 4 years (1992, 1993, 1996 and 1997) over the last 21-year period (1989-2009), and during 2006 the riffle crests were exposed between JulySeptember. The second site experienced intermittent flow for 3 years (1992, 1993 and 1997) over the last 21-year period. During 2006, the wetted width of the channel was reduced and the riffle crests exposed between July-August, although flow was maintained along the entire length of the river throughout the study.

Five benthic and five hyporheic invertebrate samples were collected monthly at each of the four sites. Obtaining benthic and hyporheic invertebrate samples required different sampling methods because of the unique characteristics of each habitat. Benthic samples were collected using a Surber sampler $\left(0.1 \mathrm{~m}^{2}, 250-\mu \mathrm{m}\right.$ mesh net $)$ over a 30 -second period, disturbing the substratum to a depth of approximately $50 \mathrm{~mm}$. Surface water temperature was measured within the water column using a digital thermometer (Hanna Instruments, Leighton Buzzard, UK). Paired with each benthic sample, 6-L hyporheic invertebrate samples were pumped from 20-cm deep PVC tubes (25-mm internal diameter) following the procedure outlined by Boulton \& Stanley (1995). The wells were inserted manually with a stainless steel bar through the gravel/alluvium and samples could be collected immediately. The technique is particularly effective due to the small diameter of the well, which minimises disturbance and compaction of the surrounding substratum and can remain in place for sampling on subsequent occasions. In addition, the sampler does not require priming with water and provides quantitative samples that has not be exposed to the atmosphere or passed through the mechanisms of the pump. This minimises the physical 
damage of specimens and also allows water quality and temperature measurements to be measured using the same sample.

Hyporheic samples were passed through a $90-\mu \mathrm{m}$ mesh sieve to retain the invertebrate fauna. Benthic and hyporheic invertebrate samples were preserved in the field in $4 \%$ formaldehyde, and returned to the laboratory for processing and identification. In the laboratory, invertebrate taxa were identified to species except Baetidae (Ephemeroptera), Chironomidae (Diptera) and Oligochaeta.

\section{Data analysis}

Prior to analysis, benthic and hyporheic abundance data were log-transformed and tested for heteroscedasticity (Levene's test) and normality. To examine differences between sites based on temporal variability and historic flow permanence, repeated-measures analysis of variance (RM-ANOVA) was used. A two-way RM-ANOVA was undertaken with month (n $=7$, months $)$ as the repeated measure factor and flow permanence $(n=2$, perennial vs intermittent) as the fixed (between-subject) factor. A one-way RM-ANOVA was used to examine differences based on the historic flow permanence of the sites. The significance (P-values) of the repeated measure factor were corrected for sphericity when required using the Greenhouse-Geiser correction. Post-hoc examination of differences between individual months was undertaken using Bonferroni multiple comparisons.

To compare data between the paired benthic and hyporheic samples from each location, the abundances of benthic taxa within the hyporheic zone were expressed as a proportion of those recorded in the benthic sample (for consistency all faunal data used were $0.1 \mathrm{~m}^{2}$ abundances for benthic Surber samples and 6-L abundances for hyporheic samples). These 
proportional data were transformed using the arcsine of the square-root of the proportion (Underwood 1997). Data for stygobitic (groundwater) fauna were analysed using the nonparametric equivalent to one-way analysis of variance (Kruskal-Wallis test) due to the heteroscedasticity of the data. All analyses were undertaken using the SPSS statistical package (Version 17).

\section{Results}

Faunal response to low flows within the benthic zone

The abundance of benthos varied during the study, with a marked reduction in July (Figure 3a). There was a significant difference in the abundance of benthic organisms recorded between months (RM-ANOVA: $\left.\mathrm{F}_{6,108}=8.33 ; \mathrm{P}<0.001\right)$ and with flow permanence $(\mathrm{RM}-$ ANOVA: $\left.F_{1,69}=13.20 \mathrm{P}<0.005\right)$ and both factors interacted significantly (RM-ANOVA: $\left.\mathrm{F}_{6,108}=2.51 ; \mathrm{P}<0.05\right)$. Differences between months were exclusively associated with reduced abundances during July versus all other months (Bonferroni multiple comparisons, all $\mathrm{P}<0.001)$. The number of benthic taxa was relatively stable from April-June before a marked decline in July (Figure 3b) which persisted at one of the intermittent sites until the end of the study. The number of benthic taxa differed among months (RM-ANOVA: $\mathrm{F}_{6,108}$ $=15.18 ; \mathrm{P}<0.001$, Figure $3 \mathrm{~b})$ and flow permanence $\left(\mathrm{RM}-\mathrm{ANOVA}: \mathrm{F}_{1,69}=5.41 ; \mathrm{P}<0.05\right)$, with a significant interaction between the two factors (RM-ANOVA: $\mathrm{F}_{6,108} 4.36 ; \mathrm{P}<0.005$ ).

The abundance of Gammarus pulex (Crustacea: Amphipoda) was compared to determine if community changes were strongly influenced by changes in the population of the most abundant taxon in the river. G. pulex in benthic samples did not differ in abundance associated with flow permanence of sites (RM-ANOVA: $\left.\mathrm{F}_{1,69}=0.97 ; \mathrm{P}=0.33\right)$ but did vary temporally $\left(\mathrm{RM}-\mathrm{ANOVA}: \mathrm{F}_{6,108}=4.38 ; \mathrm{P}<0.001\right)$, yet not in any seasonal pattern 
(Figure 4a). Abundance in June was higher than in April and September (Bonferroni multiple comparisons all $\mathrm{P}<0.05)$. There was no significant interaction between month and the flow permanence of sites $\left(\mathrm{RM}-\mathrm{ANOVA}: \mathrm{F}_{6,108}=1.02 ; \mathrm{P}=0.415\right)$.

As insect emergence might partly explain temporal trends, the overall abundance of aquatic insect larvae was examined. The number of benthic insect larvae recorded appeared relatively stable throughout the study except for a significant reduction during July at both intermittent sites (Figure 4b). There was a significant difference in the number of aquatic insect larvae between months (RM-ANOVA: $\left.\mathrm{F}_{6,108}=12.35 ; \mathrm{P}<0.001\right)$, but not with flow permanence (RM-ANOVA: $\mathrm{F}_{1,69}=3.13 ; \mathrm{P}=0.08$ ), although a significant interaction occurred between these two factors (RM-ANOVA: $\left.\mathrm{F}_{6,108}=5.80 ; \mathrm{P}<0.001\right)$.

\section{Faunal responses to low flows within the hyporheic zone}

The abundance of benthic organisms recorded within the hyporheic zone was broadly similar at all sites at the start of the study (Figure 5a). At one perennial site, there was a marked increase in abundance between April-June, and overall, abundance of benthos increased in the hyporheic zone during July and September (Bonferroni multiple comparisons, $\mathrm{P}<0.005)$. This temporal difference in the abundance of benthos in the hyporheic zone among months was significant (RM-ANOVA: $\left.\mathrm{F}_{6,108}=24.93 ; \mathrm{P}<0.001\right)$ but there was no significant difference based on flow permanence (RM-ANOVA: $\mathrm{F}_{1,69}=0.58$; $\mathrm{P}=0.45)$ nor any significant interaction (RM-ANOVA: $\left.\mathrm{F}_{6,108}=1.92 ; \mathrm{P}=0.084\right)$.

The number of benthic taxa within the hyporheic zone remained relatively stable for most of the study period but peaked significantly in September (Bonferroni multiple comparisons, $\mathrm{P}<0.001$; Figure $5 \mathrm{~b}$ ); and this temporal variation was significant (RM- 
ANOVA: $\left.\mathrm{F}_{6,108}=15.41 ; \mathrm{P}<0.001\right)$. There was no difference in the number of benthic taxa in the hyporheic zone based on flow permanence $\left(\mathrm{F}_{1,69}=0.006 ; \mathrm{P}=0.944\right)$ and no significant interaction between the two factors (RM-ANOVA: $\left.\mathrm{F}_{6,108}=1.51 ; \mathrm{P}=0.18\right)$. Stygobitic (groundwater / hypogean) macroinvertebrates were relatively rare throughout the study but increased significantly in abundance during July (Figure 5c, Kruskal-Wallis test, $\mathrm{P}<0.001)$.

Changes in the proportion of benthos within the hyporheic zone

The proportion of benthos recorded within the hyporheic zone relative to those recorded in the paired benthic samples increased markedly in July and September (Figure 6a). One perennially flowing site displayed a gradual change between April-July before a stepped reduction in August and an increase in September. Proportions differed significantly among months (RM-ANOVA: $\left.\mathrm{F}_{6,108}=27.98 ; \mathrm{P}<0.001\right)$ and with flow permanence $(\mathrm{RM}-\mathrm{ANOVA}$ : $\left.\mathrm{F}_{1,69}=13.70 ; \mathrm{P}<0.001\right)$, interacting significantly because of the pattern at the perennial site described above (RM-ANOVA: $\left.\mathrm{F}_{6,108}=6.92 ; \mathrm{P}<0.001\right)$. The proportion of Gammarus pulex recorded within the hyporheic zone relative to those in the paired benthic samples increased during July and September (RM-ANOVA: $\mathrm{F}_{6,108}=21.68 ; \mathrm{P}<0.001$, Figure $6 \mathrm{~b}$ ), especially at one of the perennial sites. There was a significant difference based on flow permanence $\left(\mathrm{RM}-\mathrm{ANOVA}: \mathrm{F}_{1,69}=4.84 ; \mathrm{P}<0.05\right)$ and a significant interaction between the two factors (RM-ANOVA: $\left.\mathrm{F}_{6,108}=3.13 ; \mathrm{P}<0.01\right)$.

\section{Discussion}

Evidence of hyporheic refuge utilisation on the Little Stour 
Benthic taxa richness and total abundance were significantly lower during July 2006 at all sites along this chalk stream. As there were parallel changes in taxa richness and benthic aquatic insect larvae abundance, some of the decline in July may reflect the natural pattern of emergence and reproduction of aquatic insects (Williams and Feltmate 1992). Therefore, when considering the influence of summer low flows on benthic communities, taxa that spend their entire life-cycle within the aquatic environment should be distinguished from those likely to emerge seasonally during the summer/low flow period. On the Little Stour River, the freshwater amphipod, Gammarus pulex, spends its entire life-cycle in the stream and, in contrast to benthic aquatic insect larvae, displayed a similar pattern of benthic abundance across all sites although it was more abundant in June. Our paired sampling design allowed us to examine this pattern more closely, and demonstrated an increase in the proportion of benthic organisms, particularly G. pulex, within the hyporheic zone relative to the benthic zone during two months (July and September), coinciding with elevated water temperatures (Figure 2) rather than the lowest discharge recorded during the drought, which occurred during August (Figure 1).

The pattern recorded does not simply reflect a reduction in river flow during drought conditions. This potentially suggests that the changes in the thermal regime and the associated changes in physicochemical characteristics (e.g. dissolved oxygen) may exert a strong control on the hyporheic community composition and abundance in this chalk stream and clearly warrants further detailed investigation. As river discharge declines and the volume of upwelling groundwater is reduced during supra-seasonal drought conditions (McKenzie-Smith et al. 2006), the mitigating effect of groundwater on stream water temperature will decline (Webb et al. 2008). This may result in some taxa actively seeking refuge within the hyporheic zone to avoid exposure to elevated temperatures and to exploit 
the thermal buffering capacity offered within the hyporheic zone. Thus, there is evidence to support the hyporheic refuge hypothesis on the Little Stour River during drought / low flow conditions, although the driver was not simply the reduction in stream discharge.

At sites associated with historic flow permanence, the response was more marked on the benthic than the hyporheic community. Benthic community abundance was typically greater at sites that had historically been dewatered whereas taxa richness was typically lower, although these patterns were not consistent over the whole study period. However, there was no significant difference based on historic flow permanence for the abundance of the dominant benthic taxon, Gammarus pulex. The abundance of benthos within the hyporheic zone did not differ among sites based on flow permanence. The different patterns recorded in benthic and hyporheic environments probably reflect the magnitude of change recorded in these adjacent habitats. The marked reduction in water levels and exposure of parts of the riverbed at historically intermittent sites lead to significant reductions in available habitat and the changes recorded within the benthic community abundance and taxa richness (James et al. 2008). Even though the hyporheic zone was not dewatered or desiccated at any stage during the study, the response of the macroinvertebrate community significantly differed between perennial and intermittent sites. This clearly demonstrates that the benthic and hyporheic communities may respond differently to the same disturbance event and so it should not assumed that samples collected from the benthic environment will be reflected in the hyporheic zone.

The results of this study also suggest that use of the hyporheic refuge may not be simply 'top-down' with benthic fauna entering the hyporheic zone as conditions deteriorate in the surface stream. The significant increase in the abundance of stygobitic taxa observed within 
the hyporheic zone (principally the amphipod Niphargus aquilex and the isopod Proasellus aquaticus) coinciding with the maximum water temperature (surface and hyporheic) also suggests that groundwater / hypogean taxa may occasionally use the shallow hyporheic zone as a refuge during adverse conditions in the groundwater environment when extremes of anoxia or $\mathrm{pH}$ may occur (Marmonier et al. 2004). Currently, little is known about refuge use by stygobitic invertebrates but their dependency on saturated habitats would imply strong behavioural adaptations to avoid desiccation.

\section{Utilization of the hypoheic refuge associated with river flow variability and permanence}

Examination of the literature centred on the hyporheic refuge hypothesis and specifically the use of the hyporheic zone as a refugium during low flow and drought indicates a highly variable response by invertebrate fauna (Table 1). Evidence of benthos utilisation of the hyporheic zone in perennial rivers and streams as a result of increased flows (spates/floods) is also equivocal (e.g., Palmer at al. 1992; Dole-Olivier et al. 1997; Fowler \& Death 2001; Olsen \& Townsend 2005). A number of studies have reported increased abundances of benthos within the hyporheic zone following spates, but also that the response was variable spatially (Dole-Olivier \& Marmonier 1992; Dole-Olivier et al. 1997). Conversely, other

studies have concluded that it did not constitute a refugium due to the significant loss (wash out / erosion) of fauna during flood events (Marmonier \& Creuzé des Châtelliers 1991; Olsen \& Townsend 2005; Palmer et al. 1992).

In contrast, low flows and flow cessation represent a fundamentally different form of hydrological disturbance to floods, which may be extended temporally and result in the gradual increase in intensity of the disturbance (Fenoglio et al. 2007; Lake 2003). These 
differences might be anticipated to elicit a different response within benthic and hyporheic invertebrate communities. Acute and/or chronic species-specific responses to changes wrought by altered proportions of groundwater and streamwater in the hyporheic environment as a result of low flows and surface drying are to be expected, and will reflect physiological tolerances to variables such as water temperature, dissolved oxygen and $\mathrm{pH}$, usually varying in concert (Brunke \& Gonser 1997; Malcolm et al. 2004).

Most of the studies reporting evidence in support of the hyporheic refuge hypothesis have been undertaken on naturally intermittent rivers (Cooling \& Boulton 1993, Griffith \& Perry 1993; Fenoglio et al. 2006). In particular Coleoptera and some Diptera larvae have been recorded in streams where surface flow has ceased (Fenoglio et al. 2006; Clinton et al. 1996). Even in desert streams and those where surface intermittency is frequent (e.g. 'mediterranean' streams experiencing seasonal drought, streams that alternately gain and lose groundwater along their course), many benthic and hyporheic invertebrates appear capable of withstanding extremes in temperature and water quality (Boulton et al. 1992; Boulton \& Stanley 1995; Datry et al. 2007). Despite this, considerable variability in faunal responses has been documented (Table 1). Some researchers report no evidence of the hyporheic zone being utilised by benthic taxa following the cessation of flow due to the complete desiccation of hyporheic sediments (Boulton \& Stanley 1995), anoxic conditions within the hyporheic zone (Smock et al. 1994) and/or the lack of interstitial habitat available due to clogging of interstices by fine sediments (Boulton 1989; Gagneur \& Chaoui-Boudghane 1991; Bo et al. 2007). However, comparing the response of the benthic and/or the hyporheic community to intermittent flow between studies is frequently difficult due to the absence of data regarding the pre- and post-drying community composition, 
variation in the duration of the 'dewatered' phase and variable timing of sampling in relation to the drying.

The faunal response to low flows within temperate streams suggests that the benthic communities are poorly adapted outside of naturally intermittent systems (Wood et al. 2005; Dewson et al. 2007; Lake 2007). In perennial streams and those where climates are more temperate, and groundwater contribution is more reliable, presumably providing greater hyporheic (and benthic) stability, there is limited evidence of utilisation of the hypoheic zone as a refugium by the benthic fauna due to a reduction in river discharge (Delucchi 1989; del Rosario \& Resh 2000; James et al. 2008). The trigger for the proportion of benthos (particularly Gammarus pulex) within the hyporheic zone of the Little Stour to increase coincided with elevated air and water temperatures and associated parameters rather that a reduction in stream discharge alone and clearly warrants further detailed investigation.

\section{Conclusion}

The results of this study demonstrate that benthic fauna utilised the hyporheic zone as a refugium during drought conditions on the Little Stour River. The tendency of the benthos to migrate into the hypoheic zone did not appear to be a response to a reduction in river discharge, but was associated with an increase in water temperature in both benthic and hyporheic habitats during two separate months (July and September), coinciding with maximum air temperatures during drought conditions (Marsh 2007). Hypogean fauna utilising the shallow hyporheic zone as a refugium also coincided with maximum water temperatures rather that the lowest flows. It is clear that the responses of macroinvertebrates within the benthic and hyporheic zones were not the same, 
demonstrating that care should be used when making inferences about hyporheic communities based on benthic sampling programmes. There is clearly a pressing need for further research which considers benthic and hyporheic communities simultaneously (James et al. 2008; Stubbington et al. 2009b) over both the medium and long term so that a greater understanding of the interactions across this dynamic ecotone can be obtained. In addition, a longer temporal resolution of responses by hyporheic invertebrate communities is required than has been used in most previous studies, so that changes in both benthic and hyporheic environments associated with individual floods or droughts can be clearly set within the context of flow regime variability (Monk et al. 2008).

The lack of consistent patterns in results of studies which have considered the hyporheic refuge hypothesis is probably not surprising given differences in flow permanence, the range of flows considered (high flows/floods through to low flow/drought) and the physical heterogeneity of the hyporheic zone among rivers. This physical heterogeneity and particularly the volume of fine sediment $(<2 \mathrm{~mm}$ in size) within the substratum may be a significant control on the shape, size and availability of interstitial habitat and on the migration of benthic macroinvertebrates into the hyporheic zone (Palmer et al. 1992; Richards \& Bacon 1994). When combined with changes in the proportions of surface and groundwater associated with upwelling and downwelling water and changes in thermal and water quality characteristics, it is clear that complex spatial and temporal changes within the hyporheic zone occur naturally and that few studies have been able to adequately quantify these changes at suitable scales with regard to the invertebrate communities inhabiting the hyporheic zone to date.

\section{Acknowledgements}


This research was supported by a Natural Environment Research Council Urgency Grant (NE/E001769/1) entitled 'The response of aquatic invertebrate fauna to supra-seasonal drought and drying in a largely perennial chalk stream'. The authors gratefully acknowledge the continued support of the Environment Agency of England and Wales and particularly Ian Humperyes, Shelagh Wilson and Kevin Grimmett. Meterological data for Manston (Kent) were kindly supplied by the British Atmospheric Data Centre (BADC). We are also grateful for the helpful and constructive comments of two anonymous reviewers and Dr Anne Robertsone on earlier drafts of this paper.

\section{References}

Bêche, L.A., Connors, P.G., Resh, V.H. \& Merenlender, A.M. 2009: Resilience of fish and invertebrates to prolonged drought in two California streams. - Ecography. 32: 778788.

Bo, T., Fenoglio, S., Malacarne, G., Pessino, M. \& Sgariboldi, F. 2007: Effects of clogging on stream macroinvertebrates: An experimental approach. - Limnologica. 37: 186192.

Boulton, A.J. 1989: Over-summering refuges of aquatic macroinvertebrates in two intermittent streams in central Victoria. - Transactions of the Royal Society of South Australia. 113: 22-34.

Boulton, A.J. 2000: The subsurface macrofauna. In: Jones, J. and Mulholland, P. (eds) Streams and Ground Waters. Academic Press, New York. pp. 337-361.

Boulton, A.J. 2007: Hyporheic rehabilitation in rivers: restoring vertical connectivity. Freshwater Biology. 52: 632-650.

Boulton, A.J. \& Stanley, E.H. 1995: Hyporheic processes during flooding and drying in a Sonoran Desert stream. 2. Faunal dynamics. - Archiv für Hydrobiologie. 134: 27-52.

Boulton, A.J., Valett, H.M. \& Fisher, S.G. 1992: Spatial distribution and taxonomic composition of the hyporheos of several Sonoran Desert streams. - Archiv für Hydrobiologie. 125: 37-61. 
Boulton, A.J., Findlay, S., Marmonier, P., Stanley, E.H. \& Valett H.M. 1998: The functional significance of the hyporheic zone in streams and rivers. - Annual Review of Ecology and Systematics. 29: 59-81.

Boulton, A.J., Harvey, M. \& Proctor, H. 2004: Of spates and species: responses by interstitial water mites to simulated spates in a subtropical Australian river. Experimental and Applied Acarology. 34: 149-169.

Brunke, M. and Gonser, T. 1997. The ecological significance of exchange processes between rivers and groundwater. - Freshwater Biology. 37: 1-33.

Clinton, S.M., Grimm, N.B. \& Fisher, S.G. 1996: Response of a hyporheic invertebrate assemblage to drying disturbance in a desert stream. - Journal of the North American Benthological Society 15: 700-712.

Coleman, M.J. \& Hynes, H.B.N. 1970: Vertical distribution of invertebrate fauna in the bed of a stream. - Limnology and Oceanography. 15: 31-40.

Cooling M.P. \& Boulton, A.J. 1993: Aspects of the hyporheic zone below the terminus of a South Australian arid-zone stream. - Australian Journal of Marine and Freshwater Research. 44: 411-426.

Datry, T., Larned, S. T., and Scarsbrook, M. R. 2007. Responses of hyporheic invertebrate assemblages to large-scale variation in flow permanence and surface-subsurface exchange. - Freshwater Biology. 52: 1452-1462.

Delucchi, C.M. 1989: Movement patterns of invertebrates in temporary and permanent streams. - Oecologia. 78: 199-207.

Dewson, Z.S., James, A.B.W. \& Death, R.G. 2007. A review of the consequences of decreased flow for instream habitat and macroinvertebrates. - Journal of the North American Benthological Society. 26: 401-415.

Dole-Olivier, M.J. \& Marmonier, P. 1992: Effects of spates on the vertical distribution of the interstitial community. - Hydrobiologia. 230: 49-61.

Dole-Olivier, M.-J., Marmonier, P. \& Beffy, J.-L. 1997: Response of invertebrates to lotic disturbance: is the hyporheic zone a patchy refugium? - Freshwatater Biology. 37: 257-276.

Dole-Olivier, M.J., Castellarini, F., Coineau, N., Galassi, D.M.P., Martin, P., Mori, N., Valdecasas, A. \& Gibert, J. 2009: Towards an optimal sampling strategy to assess groundwater biodiversity: comparison across six European regions. - Freshwater Biology 54: 777-796. 
Fenoglio, S., Bo, T. \& Bosi, G. 2006: Deep interstitial habitat as a refuge for Agabus paludosus (Fabricius) (Coleoptera: Dytiscidae) during summer droughts. - The Coleopterists Bulletin. 60: 37-41.

Fenoglio, S., Bo, T., Cucco, M. \& Malacarne, G. 2007: Response of benthic invertebrate assemblages to varying drought conditions in the Po river (NW Italy). - Italian Journal of Zoology 74: 191-201.

Fisher, S.G., Grimm, N.B., Marti, E., Holmes, R.M. \& Jones, J.B. 1998. Material spiraling in stream corridors: A telescoping ecosystem model. - Ecosystems. 1: 19-34

Fowler, R.T. \& Death R.G. 2001. The effect of environmental stability on hyporheic community structure. - Hydrobiologia. 445: 85-95.

Gagneur, J. Chaoui-Boudghane, C. 1991: Sur le rôle du milieu hyporhéique pendant l'assèchement des oueds de l'Ouest Algerien. - Stygologia. 6: 77-89.

Gandy, C.J., Smith, J.W.N. \& Jarvis, A.P. 2007: Attenuation of mining-derived pollutants in the hyporheic zone: A review. - Science of the Total Environment. 373: 435-446.

Griffith, M.B. \& Perry, S.A., 1993: The distribution of macroinvertebrates in the hyporheic zone of 2 small Appalachian headwater streams. - Archiv für Hydrobiologie. 126: 373-384.

Hose, G.C., Jones, P. \& Lim, R.P. 2005: Hyporheic macroinvertebrates in riffle and pool areas of temporary streams in south eastern Australia. - Hydrobiologia. 532: 81-90.

James, A.B.W., Dewson, Z.S. and Death, R.G. 2008. Do stream macroinvertebrates use instream refugia in response to severe short-term flow reduction in New Zealand streams? - Freshwater Biology. 53: 1316-1334.

Jones, J. and Mulholland, P. 2000 (Eds): 'Streams and Ground Waters', Academic Press, New York.

Kasahara, T., Datry, T., Mutz, M. \& Boulton, A.J. 2009: Treating causes not symptoms: restoration of surface-groundwater interactions in rivers. - Marine and Freshwater Research. 60: 976-982.

Krause, S., Hannah, D.M. \& Fleckenstein, J.H. 2009: Hyporheic hydrology: interactions at the groundwater-surface water interface. - Hydrological Processes. 23: 2103-2107.

Lake, P.S. 2000: Disturbance, patchiness, and diversity in stream. - Journal of the North American Benthological Society. 19: 573-592.

Lake, P.S. 2003: Ecological effects of perturbation by drought in flowing waters. Freshwater Biology. 48: 1161-1172. 
Lake, P.S. 2007: Flow-generated disturbances and ecological responses: floods and droughts. - In: Wood, P.J., Hannah, D.M. and Sadler, J.P. (eds.). Hydroecology and Ecohydrology: Past Present and Future. Wiley, Chichester. 75-92.

Lytle, D.A. \& Poff, N.L. 2004: Adaptation to natural flow regimes. - Trends in Ecology and Evolution. 19: 94-100.

Malcolm, I.A., Soulsby, C., Youngson, A.F., Hannah, D.M., McLaren, I.S., \& Thorne, A. 2004: Hydrological influences on hyporheic water quality: implication for salmon survival. - Hydrological Processes. 18: 1543-1560.

Marchant, R. 1995: Seasonal variation in the vertical distribution of hyporheic invertebrates in an Australian upland river. - Archiv für Hydrobiologie. 134: 441-457.

Marmonier, P. \& Creuzé des Châtelliers, M. 1991: Effects of spates on interstitial assemblages of the Rhône River. Importance of spatial heterogeneity. Hydrobiologia. 210: 243-251.

Marmonier, P., Delettre, Y., Lefebvre, S., Guyon, J. \& Boulton, A.J. 2004: A simple technique using wooden stakes to estimate vertical patterns of interstitial oxygenation in the beds of rivers. - Archiv für Hydrobiologie. 160:133-143.

Marsh, T. 2007: The 2004-2006 drought in southern Britain. Weather. 62: 191-196.

McKenzie-Smith, F.J., Bunn, S.E. \& House, A.P.N. 2006: Habitat dynamics in the bed sediment of an intermittent upland stream. - Aquatic Sciences. 68: 86-99.

Monk, W.A., Wood, P.J., Hannah, D.M. \& Wilson, D.A. 2008: Macroinvertebrate community response to inter-annual and regional river flow regime dynamics. - River Research and Applications. 24: 988-1001.

Mulholland, P.J., Helton, A.M., Poole, G.C., Hall, R.O., Hamilton, S.K. Peterson, B.J., Tank, J.L., Ashkenas, L.R., Cooper, L.W., Dahm, C.N., Dodds, W.K., Findlay, S.E.G., Gregory, S.V., Grimm, N.B., Johson, S.L., McDowell, W.H., Meyer, J.L., Valett, H.M., Webster, J.R., Arango, C.P., Beaulieu, J.J., Bernot, M.J., Burgin, A.J., Crenshaw, C.L., Johnson, L.T., Niederlehner, B.R., O’Brien, J.M., Potter, J.D., Sheibley, R.W., Sobota, D.J., \&Thomas, S.M. 2008. Stream denitrification across biomes and its response to anthropogenic nitrate loading. Nature 452: 202-205. Olsen, D.A., \& Townsend, C.R. 2005: Flood effects on invertebrates, sediments and particulate organic matter in the hyporheic zone of a gravelbed stream. - Freshwater Biology. 50: 839-853. 
Orghidan, T. 1953: Un nou demeniu de viata acvatica subterana 'Biotopul hiporeic'.

Buletinul Sectei Biologie si Stiinte Agronomice si Seciunea Geologis si Geografie, Academieri Republicci Populare Romine. 7: 3

Orghidan, T. 1959: Ein neuer Lebensraum des unterirdischen Wassers, de hyporheische Biotop. - Archiv für Hydrobiologie. 55: 392-414.

Palmer, M.A., Bely, A.E. \& Berg, K.E. 1992: Response of invertebrates to lotic disturbance

- A test of the hyporheic refuge hypothesis. - Oecologia. 89: 182-194.

Pinay, G., O'Keefe, T.C., Edwards, R.T. \& Niaman R.J. 2009: Nitrate removal in the hyporheic zone of a salmon river in Alaska. - River Research and Applications. 25: 367-375.

Prior, J. \& Beswick, M. 2007: The records-breaking heat and sunshine of July 2006. Weather. 62: 174-182.

Puig, M.A., Sabater, F. \& Malo, J. 1990: Benthic and hyporheic faunas of mayflies and stoneflies in the Ter River basin (NE Spain). - In Campbell, I.C. (Ed.): Mayflies and Stoneflies. Kluwer Academic Publishers, Dordrecht, p.255-258.

Richards, C. \& Bacon, K.L. 1994: Influence of fine sediment on macroinvertebrate colonization of surface and hyporheic stream substrates. - Great Basin Naturalist. 54: 106-113.

del Rosario, R.B. \& Resh, V.H. 2000: Invertebrates in intermittent and temporary streams: Is the hyporheic zone a refuge from drying? - Journal of the North American Benthological Society. 19: 680-696.

Sear, D.A., Armitage, P.D., \& Dawson, F.H. 1999: Groundwater dominated rivers. Hydrological Processes. 13: 255-276.

Smock, L.A., Smith, L.C., Jones, Jr. J.B. and Hooper, S.M. 1994: Effects of drought and hurricane on a coastal headwater stream. - Archiv für Hydrobiologie. 131: 25-38.

Snell, F.C. 1937: The Intermittent (or Nailbourne) Streams of East Kent. Hunt, Snell \& Co, Canterbury, UK. 71pp.

Stubbington, R. Greenwood, A.M., Wood, P.J., Armitage, P.D., Gunn, J. \& Robertson, A.L. 2009a: The response of perennial and temporary headwater stream invertebrate communities to hydrological extremes. - Hydrobiologia. 630: 299-312.

Stubbington R., Wood, P.J. \& Boulton, A.J. 2009b: Low flow controls on benthic and hyporheic macroinvertebrate assemblages during supra-seasonal drought. Hydrological Processes. 23: 2252-2263. 
Suren, A.M. \& Jowett, I.G. 2006: Effects of flood versus low flows on invertebrates in a New Zealand gravel-bed river. - Freshwater Biology. 51: 2207-2227.

Underwood, A.J. 1997: Experiments in Ecology: Their Logical Design and Interpretation using Analysis of Variance. Cambridge University Press, Cambridge. 504pp.

Williams, D.D. and Feltmate, B.W. 1992: Aquatic Insects. CAB International, Wallingford, UK. 358pp.

Williams, D.D. \& Hynes H.B.N. 1974: Occurrence of benthos deep in the substratum of a stream. - Freshwater Biology. 4: 233-255.

Webb, B.W., Hannah, D.M., Moore, R.D., Brown, L.E. \& Noblis, F. 2008. Recent advances in stream and river temperature research. - Hydrological Processes. 22: 902-918.

Wood, P.J. \& Armitage, P.D. 2004: The response of the macroinvertebrate community to low-flow variability and supra-seasonal drought within a groundwater dominated stream. - Archiv für Hydrobiologie 161: 1-20.

Wood, P.J. \& Petts, G.E. 1994: Low flows and recovery of macroinvertebrates in a small regulated chalk stream. - Regulated Rivers: Research and Management. 9: 303-316.

Wood, P.J. \& Petts, G.E. 1999: The influence of drought on chalk stream macroinvertebrates. - Hydrological Processes. 13: 387-399

Wood, P.J., Agnew, M.D. \& Petts, G.E. 2000: Flow variations and macroinvertebrate community responses in a small groundwater-dominated stream in south-east England. - Hydrological Processes. 14: 3133-3147.

Wood, P.J., Gunn, J., Smith, H. \& Abas-Kutty, A. 2005: Flow permanence and macroinvertebrate community diversity within groundwater dominated streams and springs. - Hydrobiologia. 545: 55-64. 


\section{List of Figures}

Figure 1. Mean daily discharge $\left(\mathrm{m}^{3} \mathrm{~s}^{-1}\right)$ for the Little Stour River at Littlebourne (solid line) and daily precipitation (mm) recorded at Manson, Kent, (bars) during 2006.

Figure 2. Mean $( \pm 1 \mathrm{SE})$ benthic and hyporheic water temperature $\left({ }^{\circ} \mathrm{C}\right)$ recorded at study sites on the Little Stour River (April-October 2006) coincident with benthic and hyporheic invertebrate samples. Black $=$ surface water, Grey $=$ hyporheic water.

Figure 3. Temporal variability $( \pm 1 \mathrm{SE})$ of: (a) benthic macroinvertebrate abundance $\left(\log _{10}\right)$ and (b) benthic number of taxa on the Little Stour River. Solid black bars = perennially flowing sites; grey = intermittent during three years since 1989; and white $=$ intermittent during four years since 1989 .

Figure 4. Temporal variability ( $\pm 1 \mathrm{SE})$ of: (a) benthic Gamarus pulex abundance $\left(\log _{10}\right)$ and (b) benthic aquatic insect larvae abundance $\left(\log _{10}\right)$ on the Little Stour River. Solid black bars $=$ perennially flowing sites; grey $=$ intermittent during three years since 1989; and white = intermittent during four years since 1989 .

Figure 5. Temporal variability ( $\pm 1 \mathrm{SE})$ of: (a) hyporheic macroinvertebrate abundance $\left(\log _{10}\right)$; (b) hyporheic number of taxa and (c) abundance of obligate hypogean invertebrates on the Little Stour River. Solid black bars = perennially flowing sites; grey $=$ intermittent during three years since 1989; and white $=$ intermittent during four years since 1989 .

Figure 6 . Temporal variability $( \pm 1 \mathrm{SE})$ of: (a) proportion of benthos within the hyporheic zone relative to those recorded in the benthic zone (arcsin-transformed) and (b) proportion of Gammarus pulex within the hyporheic zone relative to those recorded in the benthic zone (arcsin transformed) on the Little Stour River. Solid black bars $=$ perennially flowing sites; grey $=$ intermittent during three years since 1989; and white $=$ intermittent during four years since 1989 . 
Table 1. Published sources considering invertebrate use of the hyporheic zone associated with low flow and drought conditions: a) Studies reporting evidence in support of the hyporheic refuge hypothesis; and b) studies reporting no evidence in support of the hyporheic refuge hypothesis.

\begin{tabular}{|c|c|c|c|c|c|}
\hline & & & & & \\
\hline $\begin{array}{l}\text { a) Support Hyporheic } \\
\text { Refuge Hypothesis }\end{array}$ & Location & $\begin{array}{l}\text { Permanence } \\
\text { (I or P) }\end{array}$ & $\begin{array}{l}\text { Hydrological } \\
\text { conditions }\end{array}$ & Evidence & $\begin{array}{l}\text { Substratum } \\
\text { characteristics }\end{array}$ \\
\hline $\begin{array}{l}\text { Cooling \& Boulton } \\
1993\end{array}$ & $\begin{array}{l}\text { South Australia } \\
\text { (Australia) }\end{array}$ & I & Drying & $\begin{array}{l}\text { Fauna moved deeper within the hyporheic zone in response to } \\
\text { drought }\end{array}$ & Cobble/gravel mix \\
\hline Griffith \& Perry, 1993 & $\begin{array}{l}\text { Appalachian } \\
\text { Mountains (USA) }\end{array}$ & I & $\begin{array}{l}\text { Drying, spates } \\
\text { and acid flush }\end{array}$ & $\begin{array}{l}\text { Benthic taxa migrated into hyporheic zone in response to drought } \\
\text { conditions }\end{array}$ & Gravel $(20-25 \mathrm{~mm})$ \\
\hline Clinton et al., 1996 & Arizona (USA) & I & Drying & $\begin{array}{l}\text { Migration of taxa deeper within the hyporheic zone - primarily } \\
\text { meiofauna and Diptera larvae }\end{array}$ & $\begin{array}{l}\text { Sand and gravel (5-50 } \\
\mathrm{mm}) \text {. }\end{array}$ \\
\hline Hose et al., 2005 & $\begin{array}{l}\text { New South Wales } \\
\text { (Australia) }\end{array}$ & I & Drying & $\begin{array}{l}\text { Hyporheic community of dewatered riffles supported large } \\
\text { numbers of benthos (particularly filter-feeders) due to } \\
\text { maintenance of hyporheic discharge }\end{array}$ & $\begin{array}{l}\text { Coarse sand - gravel (2- } \\
10 \mathrm{~mm})\end{array}$ \\
\hline Fenoglio et al., 2006 & Apennines (Italy) & I & Drying & $\begin{array}{l}\text { Dytiscid beetles recorded deep }(60-90 \mathrm{~cm}) \text { within the hyporheic } \\
\text { zone }\end{array}$ & Mixed sand and gravel \\
\hline $\begin{array}{l}\text { b) Do not support } \\
\text { Hyporheic Refuge } \\
\text { Hypothesis }\end{array}$ & & & & & \\
\hline Delucchi, 1989 & New York (USA) & $\mathrm{I} \& \mathrm{P}$ & Drying & $\begin{array}{l}\text { Limited evidence of movement of benthos into hypoheic zone in } \\
\text { response to drying in intermittent rivers. No evidence of vertical } \\
\text { movement in perennial streams. }\end{array}$ & Cobbles and gravel \\
\hline Boulton, 1989 & Victoria (Australia) & I & Drying & Only hypogean taxa common in hyporheic zone during drying & $\begin{array}{l}\text { Cobble and gravel but } \\
\text { sand filled interstitial } \\
\text { spaces. Hyporheic water } \\
\text { temperatures elevated }\end{array}$ \\
\hline $\begin{array}{l}\text { Gagneur \& Chaoui- } \\
\text { Boudghane, } 1991\end{array}$ & Algeria & I & Drying & $\begin{array}{l}\text { Very low numbers of benthos in hyporheic zone during the } \\
\text { summer / dry period }\end{array}$ & $\begin{array}{l}\text { Compacted fine } \\
\text { sediments and clogging } \\
\text { reduced interstitial / } \\
\text { hyporheic habitat } \\
\text { availability }\end{array}$ \\
\hline $\begin{array}{l}\text { Boulton et al., 1992; } \\
\text { Boulton \& Stanley, } \\
1995\end{array}$ & $\begin{array}{l}\text { Sonoran Desert } \\
\text { (USA) }\end{array}$ & I & Drying & $\begin{array}{l}\text { Little overlap between benthic (epigean) and hyporheic } \\
\text { communities. As water levels declined, hyporheic zone became } \\
\text { dewatered / dry }\end{array}$ & $\begin{array}{l}\text { Mixed but primarily } \\
\text { gravel }(<30 \mathrm{~mm}) \text { and } \\
\text { sand }\end{array}$ \\
\hline Smock et al., 1994 & $\begin{array}{l}\text { South Carolina } \\
\text { (USA) }\end{array}$ & I & Drying & $\begin{array}{l}\text { No evidence of benthos using the hyporheic zone due to anoxic } \\
\text { conditions }\end{array}$ & $\begin{array}{l}\text { Sand and fine sediments } \\
\text { with limited interstitial } \\
\text { spaces }\end{array}$ \\
\hline $\begin{array}{l}\text { del Rosario \& Resh, } \\
2000\end{array}$ & California (USA) & I \& P & $\begin{array}{l}\text { Drying / low } \\
\text { flows at } \\
\text { perennial sites }\end{array}$ & $\begin{array}{l}\text { No increase of benthic taxa within hyporheic zone in response to } \\
\text { drying or flow recession }\end{array}$ & Gravel and cobbles \\
\hline James et al., 2008 & $\begin{array}{l}\text { North Island (New } \\
\text { Zealand) }\end{array}$ & $\mathrm{P}$ & $\begin{array}{l}\text { Experimental } \\
\text { reduction in } \\
\text { flow }\end{array}$ & $\begin{array}{l}\text { No evidence of benthos utilisation of the hyporheic zone as a } \\
\text { refugium as long as surface water persisted }\end{array}$ & $\begin{array}{l}\text { Mixed (boulder, cobble, } \\
\text { gravel and fines }<2 \mathrm{~mm} \text { ) }\end{array}$ \\
\hline
\end{tabular}





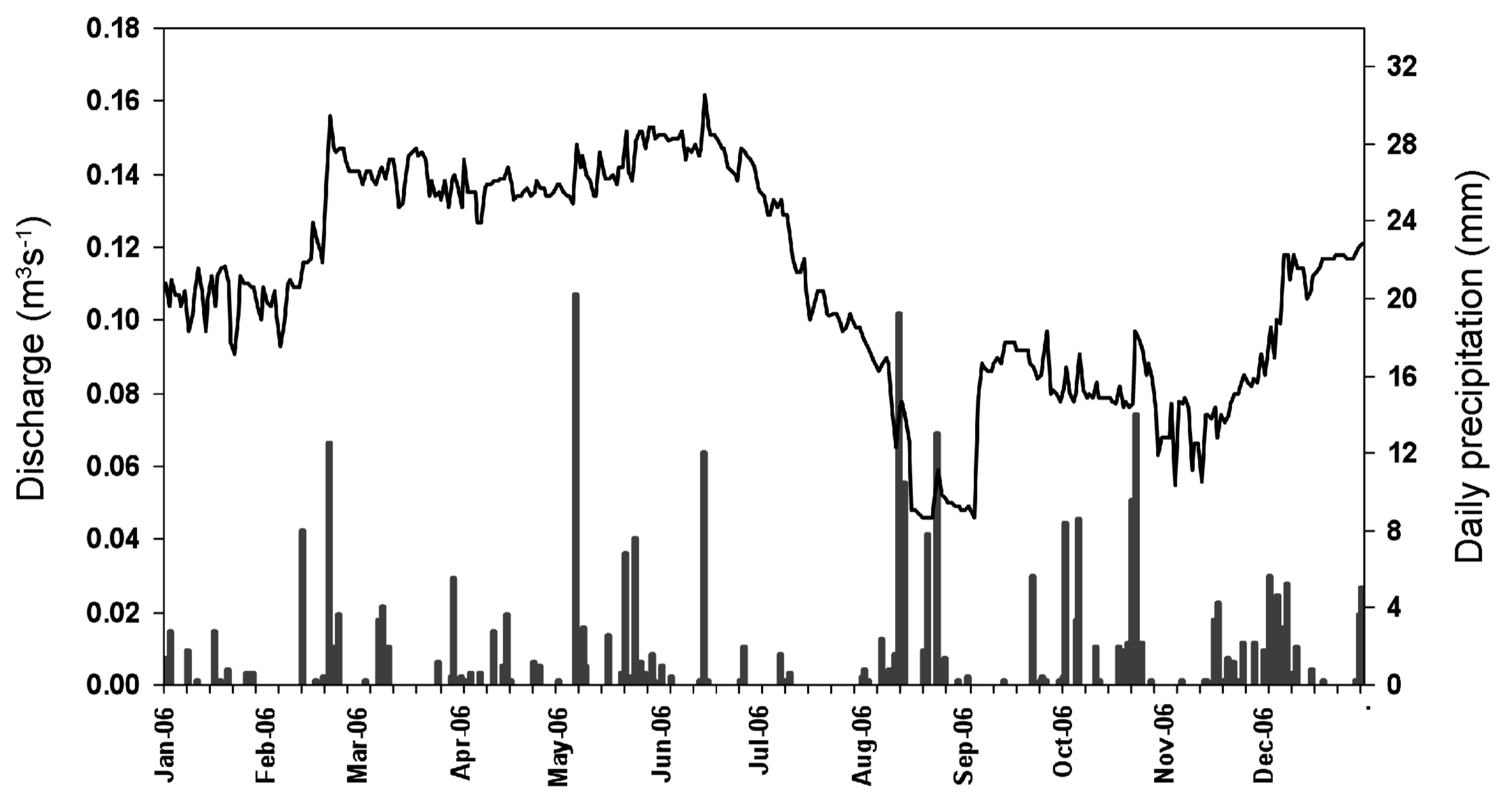




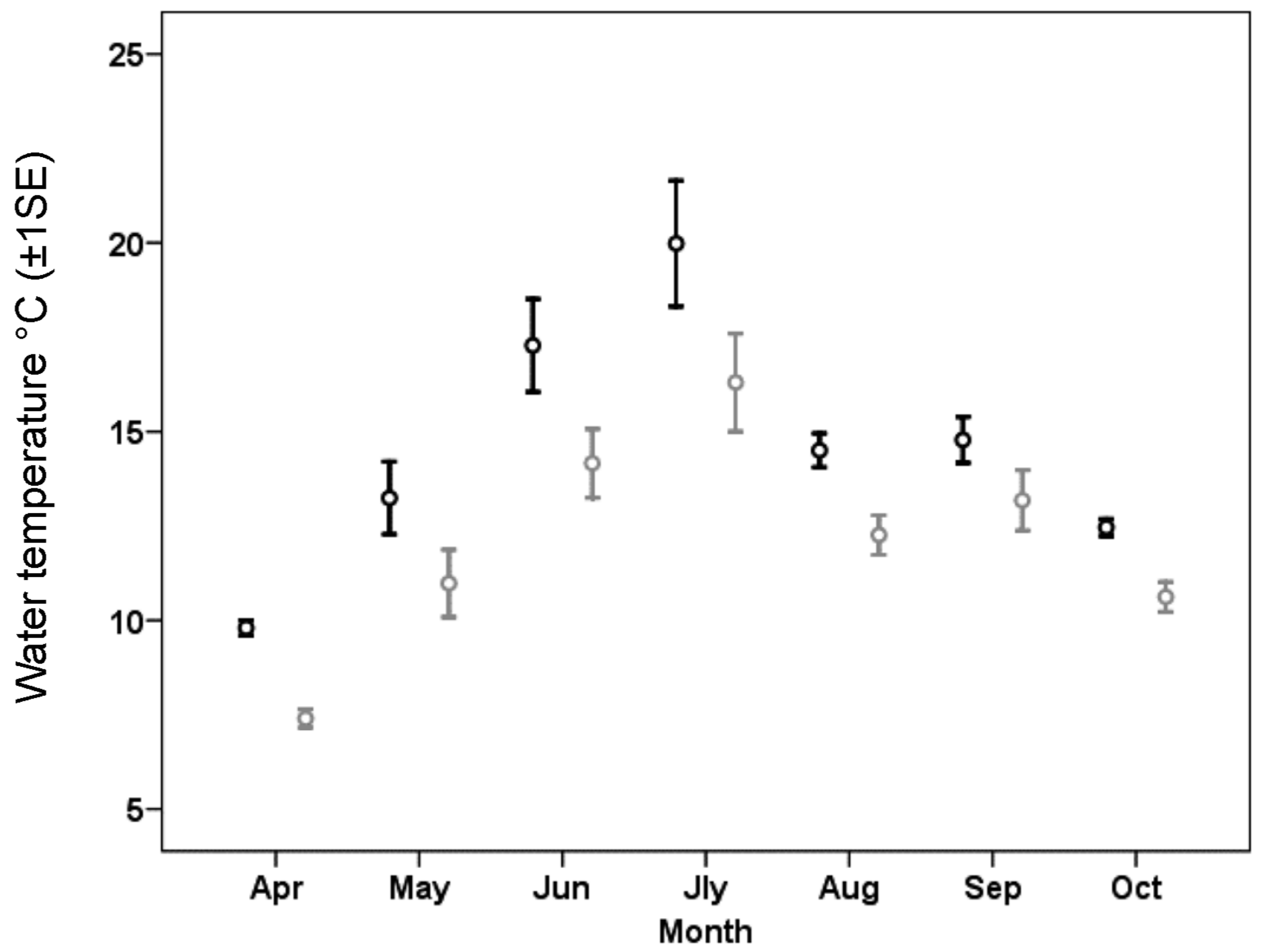



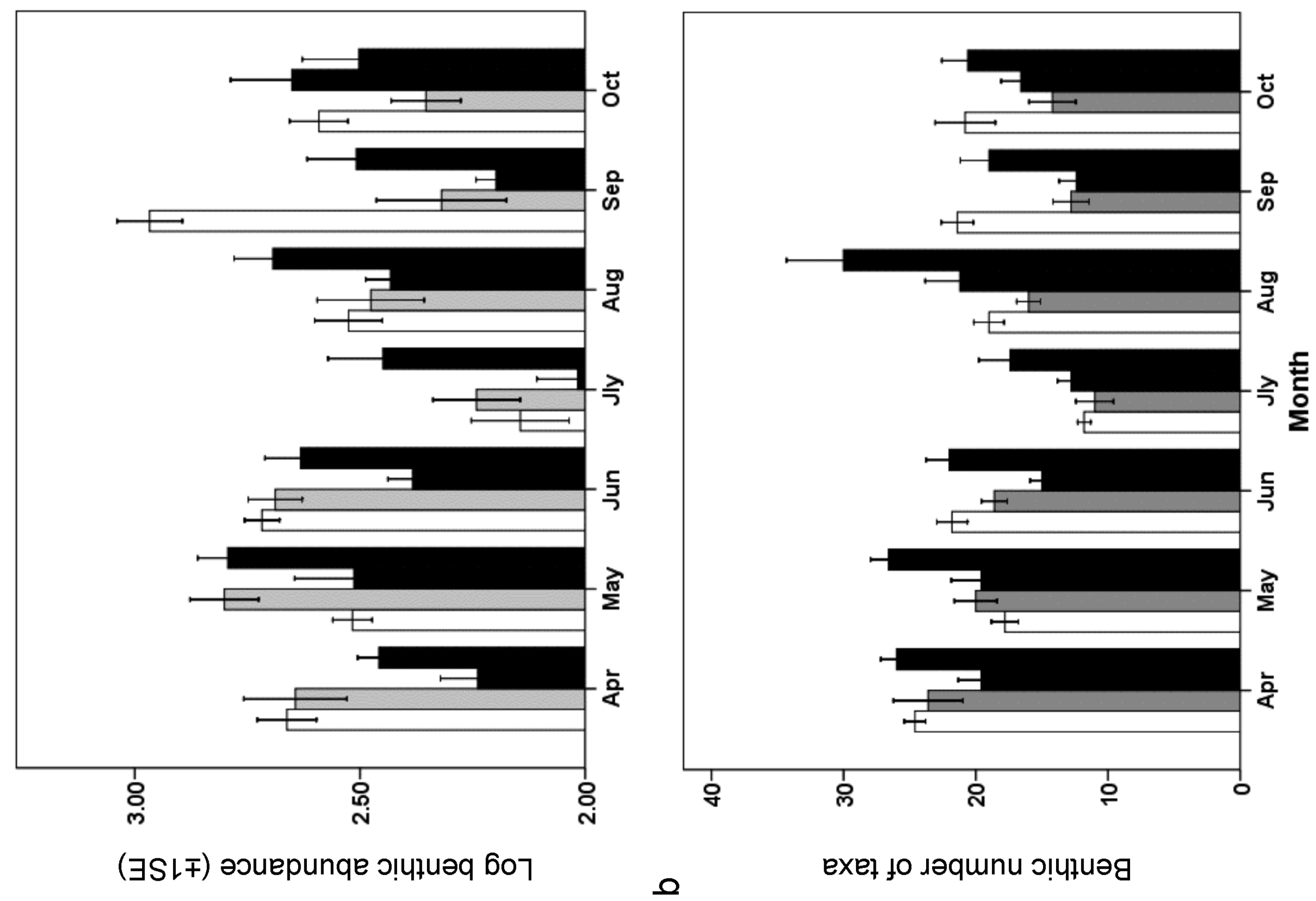

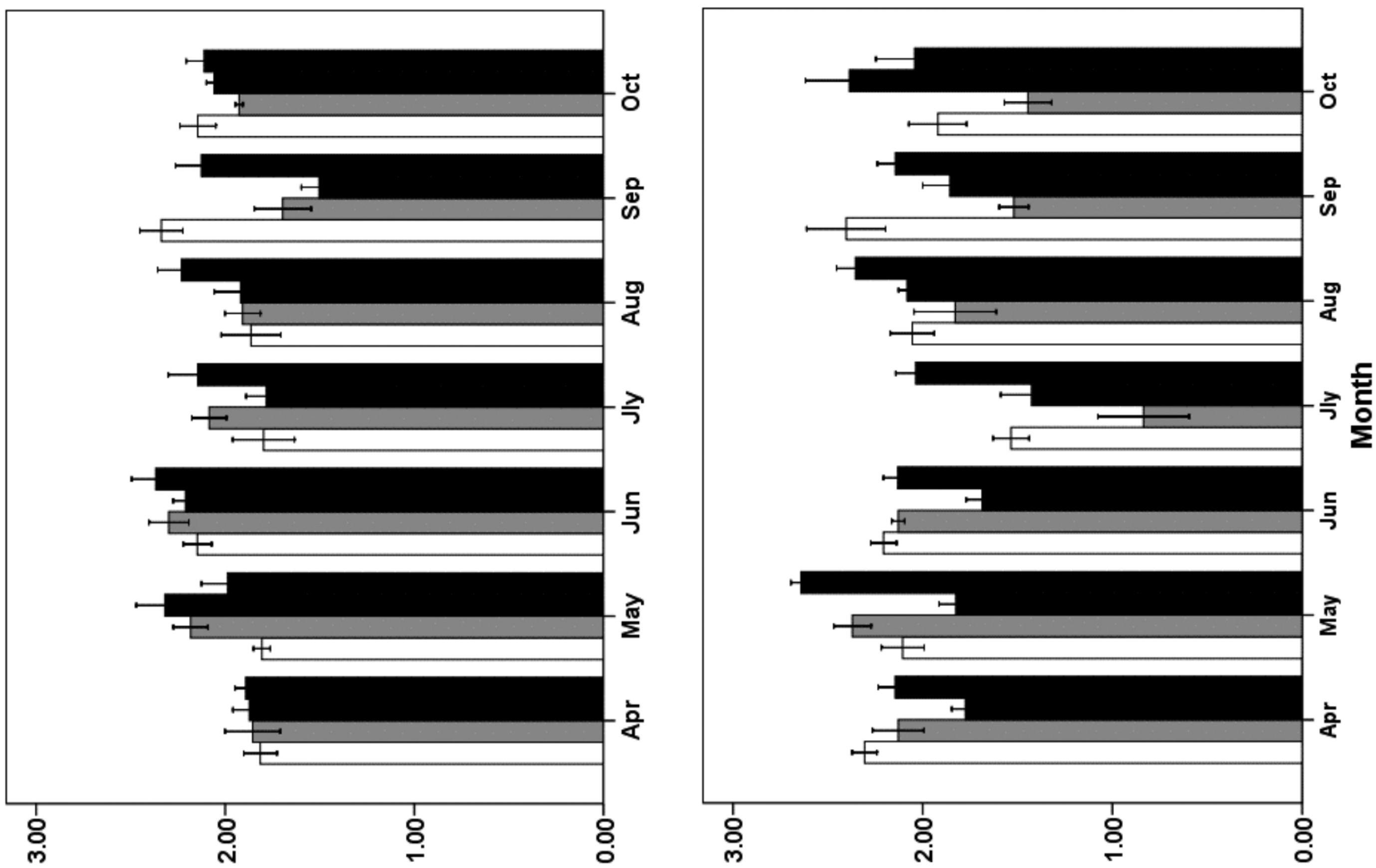

( $\exists S L \mp)$ әouepunqe xə|nd snjemue 6оา 


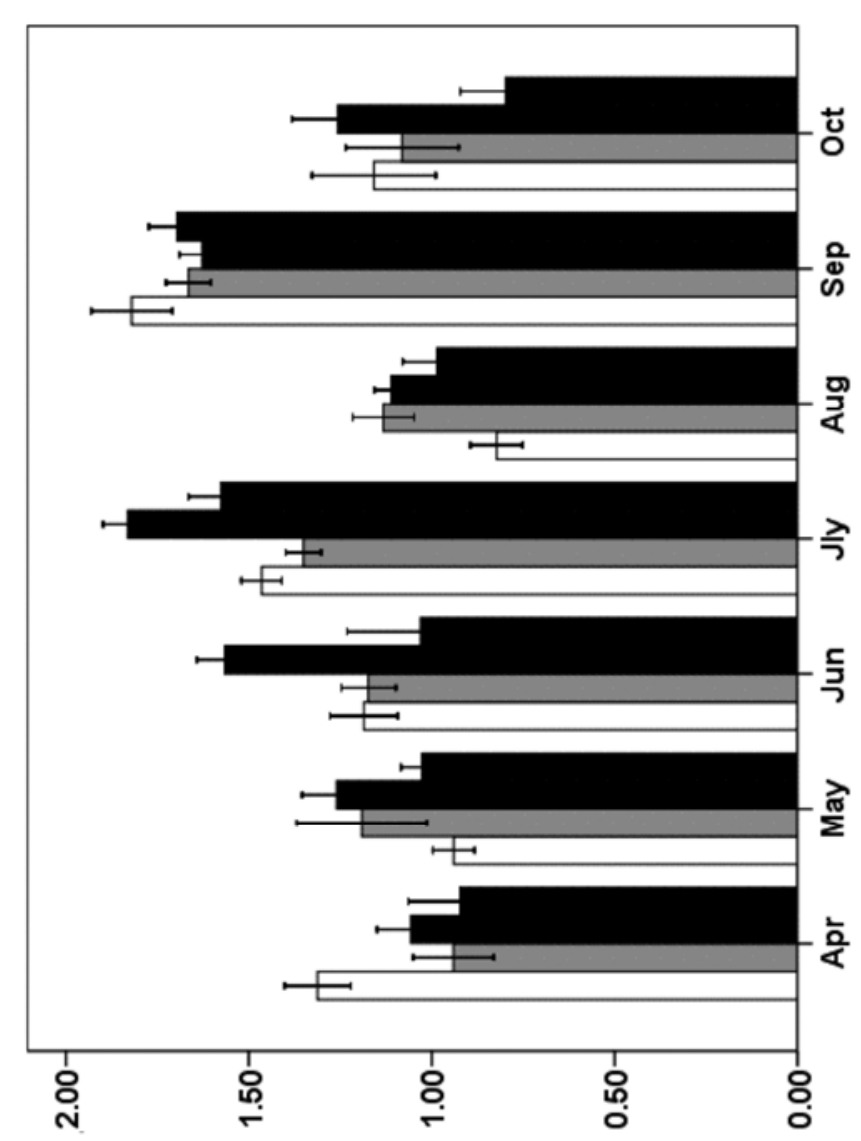

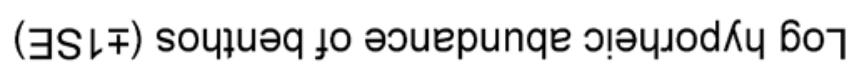
(ర)

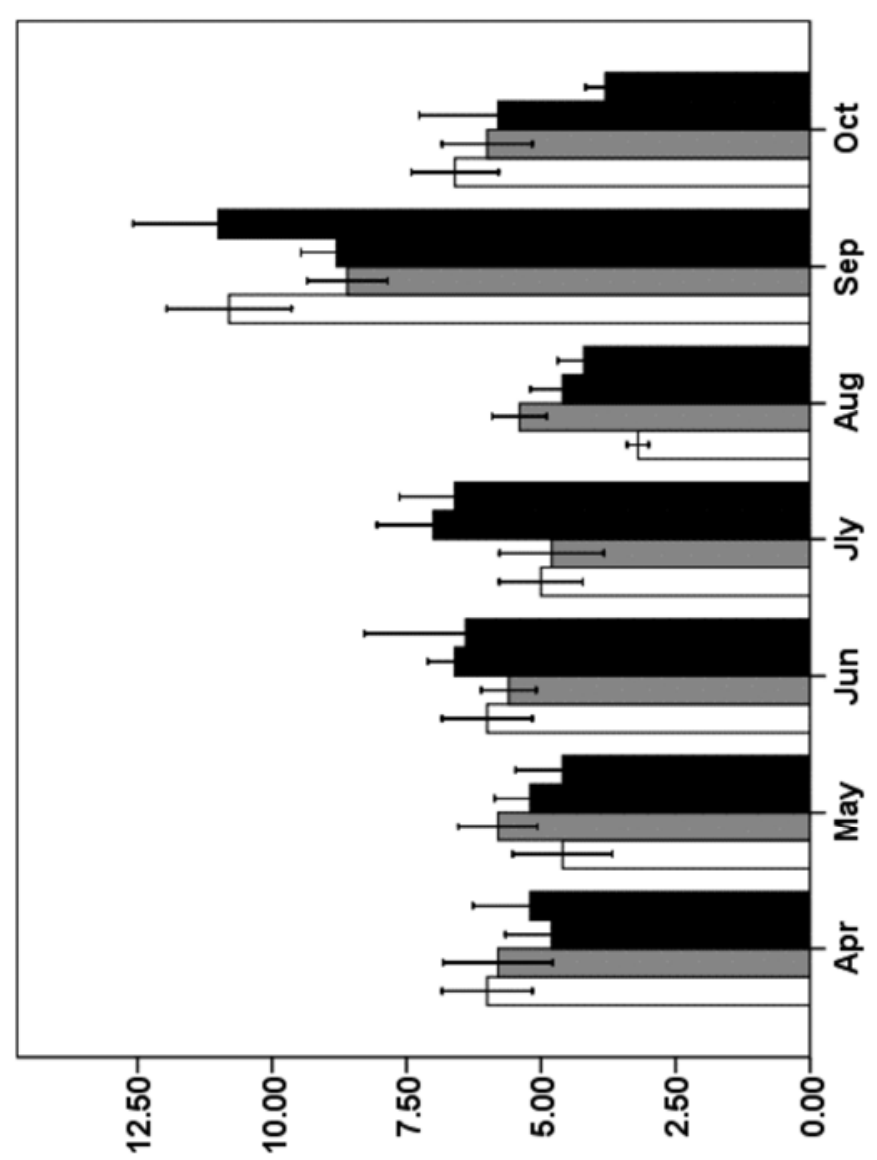

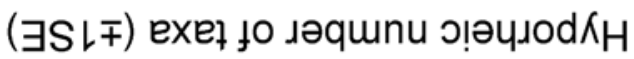

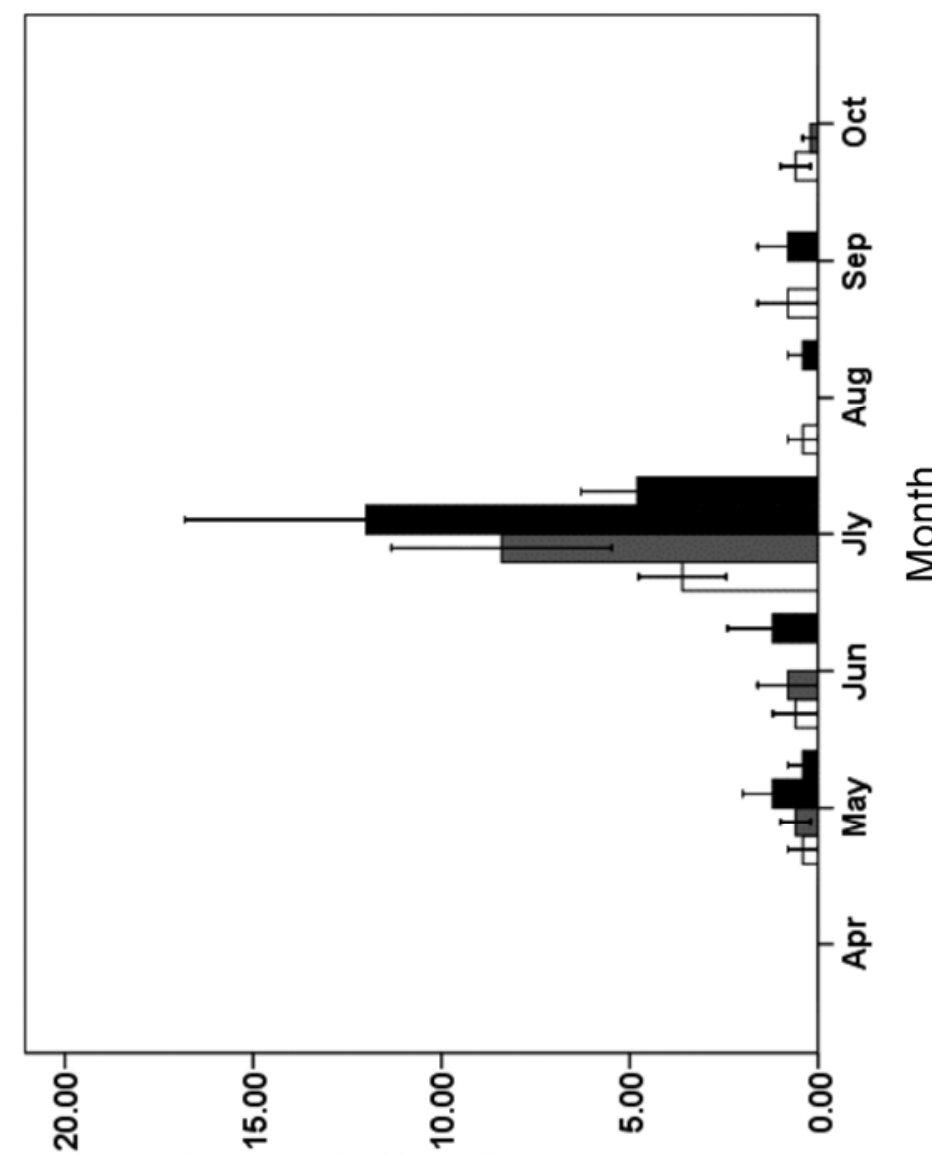

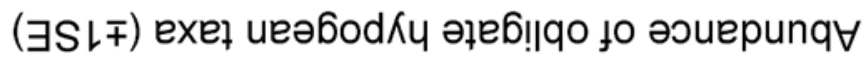
으 0 


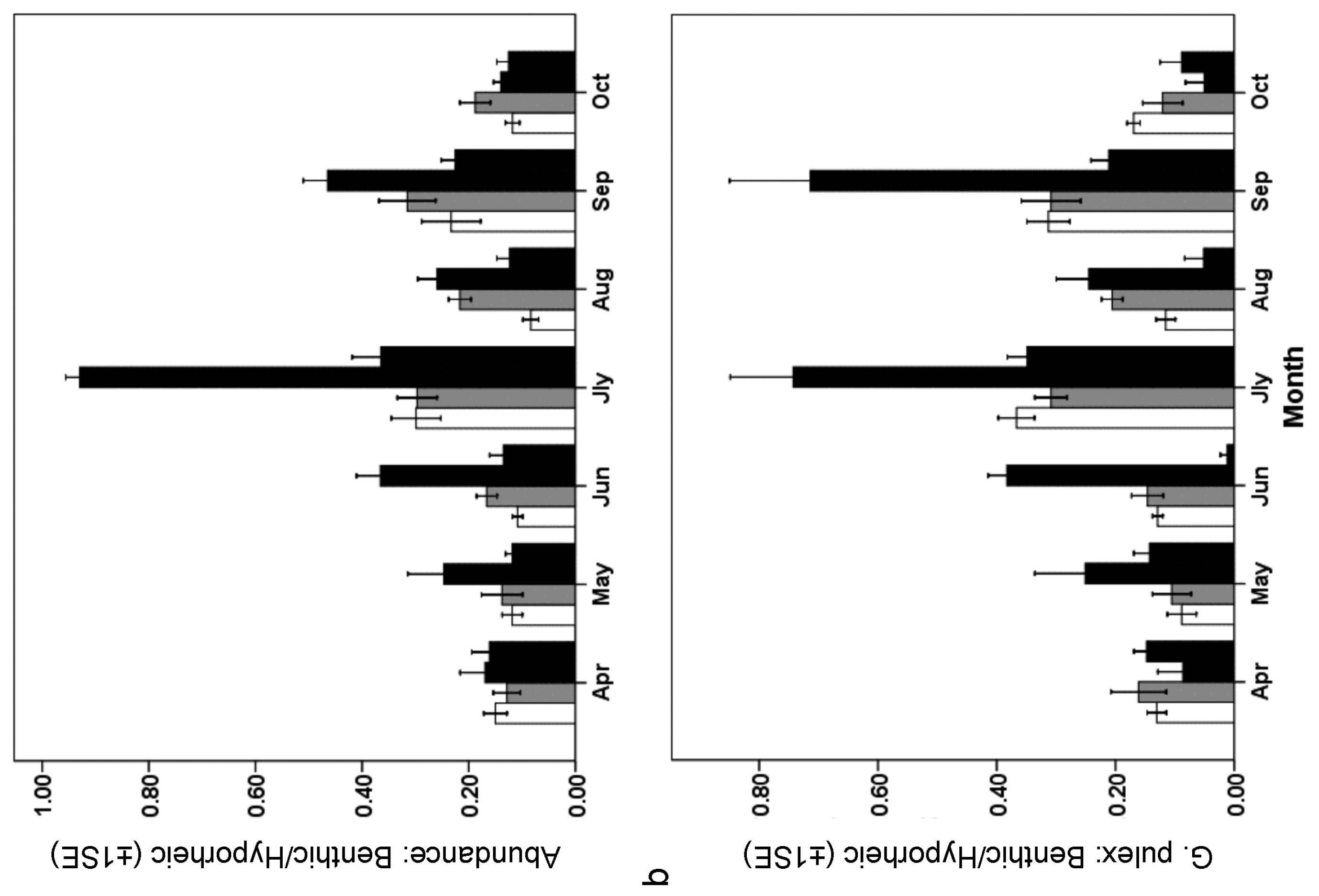

